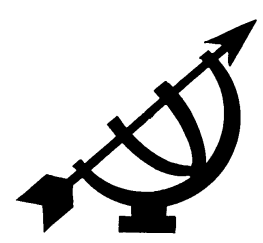

\title{
'n Perspektief op die voorkoms van dissiplineprobleme in Afrikaanse skole
}

\author{
P.J. Mentz \& C.C. Wolhuter \\ Skool vir Opvoedkunde en Opleiding \\ Fakulteit Opvoedingswetenskappe \\ Potchefstroomse Universiteit vir $\mathrm{CHO}$ \\ POTCHEFSTROOM \\ E-pos: soopjm@puknet.puk.ac.za \\ sooccw@puknet.puk.ac.za
}

\section{S.C. Steyn}

Skool vir Onderwysersopleiding (mensgerigte skoolvakke)

Fakulteit Opvoedingswetenskappe

Potchefstroomse Universiteit vir $\mathrm{CHO}$

POTCHEFSTROOM

E-pos: smsscs@puknet.puk.ac.za

Abstract

Discipline problems in Afrikaans schools - a perspective

The aim of this article is to report on an investigation into the incidence and extent of discipline problems in Afrikaans schools, especially in the light of fundamental changes that have occurred during the past ten years within these schools. This report is also placed in the context of a reformational perspective on discipline, disciplinary problems and the role of educators in eradicating such problems. An empirical investigation was conducted, in which the experience of 76 principals of Afrikaans schools was probed by means of two questionnaires.

The responses revealed that the overwhelming majority of principals opined that the discipline situation at their schools was either average or good, and that feelings of despondence and defaitism regarding discipline did not exist. In line with new official education policy, they had implemented new procedures, in order to address discipline problems. The incidence of disciplinary problems was not higher in multicultural schools. The incidence was, however, higher at urban than in rural schools. Parental involvement was identified as an essential factor in combatting disciplinary problems in schools. It was also found, on the basis of a Biblically-based view of education, that 
parents and other educators had a significant role to play in eradicating such problems.

Opsomming

'n Perspektief op die voorkoms van dissiplineprobleme in Afrikaanse skole

Die doel van die artikel is om verslag te doen van navorsing oor die voorkoms van dissiplineprobleme in Afrikaanse skole, veral in die lig van die fundamentele veranderinge wat die afgelope tien jaar in skole plaasgevind het. Dié verslag word geplaas binne die konteks van 'n reformatoriese beskouing oor dissipline, dissiplineprobleme en die rol van die opvoeder in die hantering van sulke probleme. 'n Empiriese ondersoek is uitgevoer, waar die ervaring van 76 hoofde van Afrikaanse skole deur middel van vraelyste ondersoek is. Die response het getoon dat die oorgrote meerderheid van die hoofde die dissiplinesituasie in hulle skole as gemiddeld of goed beskou het, en dat 'n gevoel van moedeloosheid en defaitisme ten opsigte van dissipline nie bestaan nie. Hulle het nuwe prosedures ooreenkomstig die nuwe onderwysbeleid in werking gestel, ten einde dissiplineprobleme te hanteer. Die voorkoms van dissiplineprobleme is nie groter in multikulturele skole nie. Die voorkoms is egter hoër in stedelike as in plattelandse skole. Ouerbetrokkenheid is ook geïdentifiseer as 'n essensiële faktor in die bekamping van dissiplineprobleme by skole. Vanuit 'n Bybelsbegronde beskouing op opvoeding is bevind dat die rol van die ouer en ander opvoeders in die bekamping van sulke probleme van besondere betekenis is.

\section{Probleemstelling}

Navorsingsverslae waarin die omvang en aard van leerderdissipline op skool bespreek word, toon dat die algemeenste dissiplineprobleme op skool eeue lank reeds bestaan en steeds min of meer dieselfde is (Oosthuizen et al., 2003; Pretorius, 1979:146-148). Daar is egter ook nuwe probleme eie aan die tyd. Volgens Fields (2000) is dissipline op skool een van die grootste bronne van kommer by ouergemeenskappe in Australië. Navorsing toon egter dat $80 \%$ van die opvoeders in Australië meen dat dissiplineprobleme binne sowel as buite die klas nie baie ernstig van aard is nie. Soortgelyke studies in Brittanje in 1986 en 1994 toon dat die meeste probleme wat deur opvoeders ervaar is, relatief matig is. Fields (2000) stel dat die beeld wat deur die media van skole in Australië, die VSA en Brittanje voorgehou word, totaal van mekaar verskil. In Australië is daar ' $n$ voortdurende en selfs groeiende persepsie dat gedragsprobleme in skole aansteeklik is, dat opvoeders nie daarin slaag om orde te handhaaf nie, en dat skoolbesture nie die veiligheid van leerders kan waarborg nie (McCarthy et al., soos aangehaal deur Fields, 
2000). Die oorgrote meerderheid voorvalle van wangedrag in primêre skole in Australië is matig van aard, en hou verband met onder andere onoplettendheid, klasreëls wat nie gehoorsaam word nie en take wat nie uitgevoer word nie.

Kommer oor ontwrigtende en antisosiale gedrag in skole in die VSA word versterk deur mediaberigte oor gewapende leerders in skole. Onlangse sensasiesoekende en wraakskietvoorvalle by leerders so jonk as 11 jaar, en onlangse voorvalle van geweld in 'n middelklasskool in Littleton in Colorado, het gelei tot die dood van 14 leerders en 'n onderwyser. Die Columbine-tragedie in die VSA, waar daar op leerders by 'n skool geskiet is, het ook opnuut die aandag op die probleem van geweld in skole gevestig (Dodd, 2000).

Die algemeenste dissiplineprobleme op skool in die VSA (volgens Bear, 1998) is eeue lank steeds dieselfde, naamlik tergery, uit die beurt praat, opstaan uit sitplekke, gebrek aan respek vir onderwysers en afknouerigheid. Daar het egter ook nuwe dissiplineprobleme na vore getree. Dwelmmisbruik, geweld/gevegte en bendes wat vroeër jare feitlik onbekend was, word deesdae aangedui as die tweede grootste probleem in Amerikaanse openbare skole.

Dit blyk dat minder ernstige en nie-gewelddadige voorvalle van misdaad meer dikwels voorkom as ernstige, gewelddadige misdaad. Dit blyk ook dat misdaad in sekere geografiese areas of skole gekonsentreer is, aangesien $43 \%$ van die openbare skole in 'n ondersoek in die VSA gerapporteer het dat daar geen voorvalle van misdaad in die jaar 1996 tot 1997 voorgekom het nie. Sewe en dertig persent van die skole het in dieselfde ondersoek aangedui dat daar in daardie jaar tussen een en vyf voorvalle van misdaad plaasgevind het, terwyl $20 \%$ gerapporteer het dat daar in daardie jaar ses of meer gevalle van misdaad voorgekom het (Anon., 2002).

Lastige gedrag van leerders soos geïdentifiseer deur opvoeders in 'n studie in Brittanje is die volgende: uit hul beurt praat, swak maniere, onbeskoftheid, leerders wat ander pla en rusteloosheid. Geeneen van hierdie gedragspatrone is deur die onderwysowerhede as ernstige ontwrigtende gedrag beskou nie.

Murray (1995) rapporteer dat die gedrag van leerders in primêre skole in Suid-Australië toegeskryf kan word aan 'n klein groepie leerders in die skool. Verbale of fisies aggressiewe en gewelddadige gedrag teenoor opvoeders en leerders word dikwels deur die media oordryf. Die probleem is egter dat hierdie enkele voorvalle van 
wangedrag baie tyd en energie van personeel verg en hoë eise aan die skool, regering en gemeenskap stel.

Dit is duidelik dat dissiplineprobleme by leerders ' $n$ universele verskynsel is. Vrae ontstaan onvermydelik oor die aard en omvang van hierdie probleme in Suid-Afrika. In skole met oorwegend Afrikaanssprekende leerders het daar in die afgelope tien jaar groot veranderinge plaasgevind. Dit is algemeen bekend dat lyfstraf in 'n groot mate as vorm van dissipline in Afrikaanse skole gebruik is voordat dit deur die Suid-Afrikaanse Skolewet verbied is.

In hierdie artikel word gefokus op die veranderde siening van dissipline in skole met oorwegend Afrikaanssprekende leerders. Die probleemvrae wat rigtinggewend vir hierdie navorsing was, is die volgende:

- Wat is die aard en omvang van dissiplineprobleme in 'n aantal geselekteerde lande?

- Watter oplossings word in tersaaklike vakliteratuur aangebied vir dissiplineprobleme in hierdie lande?

- Wat is die hoofde van skole vir Afrikaanssprekende leerders in Suid-Afrika se siening van die aard en omvang van dissiplineprobleme in skole?

Ten einde die vraagstuk van dissiplineprobleme in skole aan die hand van hierdie probleemvrae te ondersoek, is die volgende stappe gevolg:

- 'n Studie van tersaaklike vakliteratuur is onderneem ten einde vas te stel wat die aard en omvang van hierdie soort probleme in 'n aantal lande is en wat in hierdie lande gedoen word om die probleme die hoof te bied.

- 'n Empiriese ondersoek is onderneem in 76 skole met oorwegend Afrikaanssprekende leerders ten einde vas te stel wat die hoofde van hierdie skole se siening oor die aard en omvang van dissiplineprobleme in hierdie skole is.

\section{Prinsipiële besinning}

In 'n bespreking soos in hierdie artikel kom 'n hele aantal sake na vore wat prinsipiële besinning verg. Die volgende is voorbeelde daarvan: dissiplineprobleme, gedragsprobleme, handhawing van orde, ontwrigtende en antisosiale gedrag, die probleem van geweld, dwelmmisbruik, geweld en gevegte, bendevorming, misdaad, lastige gedrag van leerders, aggressiewe gedrag, wangedrag, 'n verander- 
de siening van dissipline, die rol van die ouers, 'n gebrek aan dissipline by leerders, die rol van die skool, die opvoeders, die samelewing, die leerders in die voorkoms van dissiplineprobleme, die opvoedingstaak, en vele meer. Elkeen van hierdie fasette van die probleem wat in hierdie artikel aandag kry, verdien prinsipiële besinning, in hierdie geval vanuit 'n reformatoriese of Bybelsgegronde denkraamwerk. Dit sou egter boekdele verg om sodanige besinning oor elkeen van hierdie fasette te doen. Die bespreking moet dus noodgedwonge beperk word tot twee aspekte van die probleem onder bespreking, naamlik dissiplineprobleme en die rol van die ouer en ander opvoeders in die bekamping daarvan. Binne so ' $n$ opset kan die nodige beginselgrondslag vir die bespreking geskep word.

Die inleidende artikel tot hierdie bundel, getitel "' $n$ Beginselgrondslag vir gesag, vryheid, orde en dissipline in die onderwysopset van die vroeg-21ste eeu" bied die oorkoepelende fundering vir die problematiek wat hier aan die orde kom (vgl. veral 2.2 in verband met waardes; 4.3 in verband met orde, en 4.4 in verband met dissipline). Die beginselstandpunt wat in genoemde artikel uiteengesit is, kan kortliks soos volg saamgevat word.

Opvoeding vanuit 'n Bybelse perspektief is om opvoedelinge, dus ook leerders, toe te rus vir diens, selfs al sou sodanige diens deur die sonde aangetas wees (Van Dyk, 1997:40). Deur opvoeding moet leerders gelei en toegerus word om die wil van God te doen, en hierdie "doen" dui op diens. Liefde vir God en die naaste kom neer op diens aan God en die naaste. Wat 'n opvoeder dus ook al doen, dit moet bydra tot die opvoedeling se vermoë om hierdie diens te kan lewer. Die diens van God bestaan uit twee dele, meen Van Dyk (2000:66): dit dui op rentmeesterskap, met ander woorde om te sorg vir die self, die naaste en die skepping in die algemeen; die diens bestaan ook in die huidige bedeling uit die bestryding van sonde. Die opvoedeling moet toegerus word om gesondmaking te kan doen, om versoening teweeg te bring, en om vrede te kan maak. Die mens is omring van skeefgetrokkenhede en gebrokenheid weens die sonde: in die persoonlike lewe, in verhoudings met ander, en in die skepping self.

Hierdie feit bring 'n ander perspektief op dissipline na die oppervlak: Dissipline - in die lig van die Bybel - impliseer naamlik niks anders as dissipelskap nie. Dissipelskap in die volste sin van die woord is om Jesus Christus met oorgawe te volg. 'n Ware dissipel is iemand wat nie slegs die Woord (wil, wette) van God hoor nie, maar dit ook doen. Die uiteindelike doel van die lewe is om in sowel woord as 
daad ooreenkomstig die wil van God te leef. Die uiteindelike doel van opvoeding is derhalwe om die opvoedeling te lei, toe te rus en in staat te stel om só te wil leef (Van Dyk, 1997:41). Die sonde het dit egter baie moeiliker gemaak om hierdie doel te bereik. Die teenwoordigheid van die sonde het ook nou 'n nuwe dimensie tot dissipelskap toegevoeg, naamlik dat die opvoedeling gelei, toegerus en in staat gestel moet word om die gebrokenheid van die skepping, van die self, van die verhoudings met ander mense, oral waar hy of sy dit teëkom, te bestry en gesond te probeer maak.

Een van die vrae wat altyd binne die raamwerk van 'n lewensopvatting na vore kom, is: Wat het skeefgeloop met die omstandighede waarin ons ons bevind? Ook word gevra: Hoe moet ons die boosheid en die gebrokenheid in die wêreld verstaan en die hoof bied? (Middleton \& Walsh, 1995:11). Vanuit 'n Bybelsbegronde denkraamwerk besef Christene dat dinge (nog nie) is soos dit behoort te wees nie. Fernhout (1997: 87) is van oordeel dat die mens, weens die teenwoordigheid van die sonde, in 'n "gewonde wêreld" leef. Die hooftema van hierdie artikel, naamlik die voorkoms van dissiplineprobleme in skole, moet teen hierdie agtergrond gesien word. Sonder die teenwoordigheid van sonde in die mens se lewe sou leiding tot dissipelskap probleemloos gewees het; nou, egter, is dit deurspek van probleme - in al die vorme hierbo vermeld, en wat regdeur hierdie artikel genoem word.

Die teenwoordigheid van die sonde in die lewe van die mens het ook 'n nuwe dimensie tot opvoeding toegevoeg. In wese is opvoeding die proses om 'n nuwe geslag te help en toe te rus om betekenisvol aan die hele lewe van die betrokke groep te kan deelneem (Fernhout, 1997:89). Opvoeding is om te lei, te help, te "dissiplineer" (in die sin van dissipelskap), en instaatstelling tot roepingsvervulling in diens van God en die naaste. Die nuwe dimensie wat nou toegevoeg word, is dat daar ook gereken moet word met die "brokenness and suffering in a fallen world" (Fernhout, 1997: 80). Toegepas op die rol wat die ouer, die onderwyser en die skool in die algemeen as opvoedings-"agente" in die lewe van die kind (die opvoedeling, die leerder) speel: hulle moet die kind lei, toerus en in staat stel om die gebrokenheid (byvoorbeeld in verhoudings tussen mense) te herken, dit te bestry en die wonde wat deur die sonde geslaan is te heel. Hulle moet gelei en geleer word om die vrede tussen mense te herstel. Ook deur hierdie werk moet hulle kan toon dat hulle ware dissipels van Jesus Christus is, of besig is om op die pad soontoe te vorder. Geen wonder dus dat Van Dyk (2000:66) die opvoeder aanspoor om hom- of haarself af te 
vra: "Is your classroom a place where such servanthood is demonstrated and practised?"

Wanneer, in die uiteensetting wat hierna volg, daar sprake is van "dissiplineprobleme" en die rol wat byvoorbeeld die leerder, die opvoeder (onderwyser en ouer), die skool en die breë samelewing in die teenwoordigheid van sodanige probleme speel, dan lê hierdie siening van dissipline, "probleme" en opvoeding ten grondslag daaraan. 1

\section{Oorsig uit vakliteratuur: perspektiewe vanuit 'n aantal lande}

Die volgende is 'n oorsig van die buitelandse ervaring van leerderdissipline op skool. Die fokus is op daardie aspekte van leerderdissipline wat in dié empiriese ondersoek beklemtoon word, te wete die stand van leerderdissipline, die rol van ouers, die effek van die grootte van die skool en die invloed van onderwysers se gesindheid. Daar moet eerstens gestel word dat die meeste wetenskaplike literatuur wat oor leerderdissipline beskikbaar is, betrekking het op hoofsaaklik drie lande, naamlik die Verenigde State van Amerika, die Verenigde Koninkryk en Australië. Dit kan toegeskryf word aan 'n baie akute probleem in die Vergelykende Opvoedkunde, naamlik dat die senusentrum van die internasionale navorsingsnetwerk WesEuropa en Noord-Amerika is, waar die meeste universiteite, navorsers, navorsingsinstellings, uitgewers en wetenskaplike tydskrifte gesetel is, en waar hierdie lande se onderwysstelsels en -probleme navorsingsvoorkeur geniet (Altbach, 1982:470).

\subsection{Die stand van leerderdissipline}

In hulle opname van onderwysers se persepsies het die Eltonkommissie in die Verenigde Koninkryk bevind dat een uit ses sekondêreskool- en een uit tien primêreskool-onderwysers van mening was dat dissiplineprobleme in hulle skole "ernstig" is (Department of Education and Science and the Welsh Office, 1989: 62). Volgens Fields (2000) het sowel die Gallup- as Langdonopname in die Verenigde State van Amerika aangedui dat die

1 Ruimte ontbreek om sekere samelewingsteoretiese grondslae ook hier in te voeg. Die rol van die ouerhuis, die skool en die beheerliggaam in die veroorsaking en bestryding van dissiplineprobleme verg sodanige besinning. Die gedagte van die individualiteit van die leerder, die diversiteit (taal, godsdiens ensovoorts) in skole, en dies meer, verg ook prinsipiële besinning. 
gebrek aan leerderdissipline in skole 'n groot probleem is - na die mening van sowel onderwysers as die breër gemeenskap. Die landwye Langdon-opname het byvoorbeeld gevind dat 58\% van die onderwysers se klasse gereeld deur wangedrag van leerders ontwrig word (Fields, 2000). In Australië is leerderdissipline in skole een van die hoofbekommernisse van ouers (Johnson, 1993).

Wat die aard van dissiplineprobleme betref, is dit veral geringe probleme wat oorheers. Soos reeds vermeld, kom ernstige dissiplineprobleme (misdaad en geweld) minder dikwels voor. Fields (2000) het 30 onderwysers in 'n stad in Queensland gevra om die leerder in sy of haar klas te identifiseer wat die meeste probleme veroorsaak en om sy/haar gedrag volgens die "Walker Problem Behaviour Identification Checklist" te beskryf, en dit in 'n rangorde van belangrikheid en ernstigheid te plaas. Die algehele rangorde was soos volg: Bo-aan die lys was die noodsaak van volgehoue en voortdurende toesig, gevolg deur die ongehoorsaamheid aan die uitvoering van eenvoudige opdragte. Rangordelik daarop volg die volgende: 'n onophoudelike gevroetel met penne, potlode en ander items; die feit dat leerders aangepor moet word om hulle werk te doen; leerders wat uit hulle beurt praat, fluister, lag en giggel; die gebrek aan motivering; die feit dat hulle aandag maklik afgetrek word; leerders se behoefte aan aandag.

\subsection{Die oorsake/korrelate van dissiplineprobleme}

Die oorsake/korrelate van dissiplineprobleme volgens die beskikbare vakliteratuur kan in die volgende vyf kategorieë gegroepeer word:

- leerderverwante faktore

- opvoederverwante faktore

- skoolverwante faktore

- ouerverwante faktore en

- samelewingsverwante faktore

Leerderverwante faktore hou verband met die ouderdom/fase van leerders. Dissiplineprobleme kom byvoorbeeld meer in hoërskole as in laerskole voor (Department of Education and Science and the Welsh Office, 1989: G2; Fields, 2000; National Center for Education Statistics, 2002).

Opvoederverwante faktore sluit in die opvoeder se bevoegdheid (kompetensie) sowel as sy gesindheid. Die verslag van die Elton- 
kommissie dui op 'n groot mate van eenstemmigheid oor die spektrum van die onderwyssektor (opvoeders, skoolhoofde, onderwysprofessionele liggame, ens.) dat 'n opvoeder se algehele bevoegdheid 'n sterk invloed op sy leerders se gedrag het (Department of Education and Science and the Welsh Office, 1989:67). Dit kan beredeneer word dat suksesvolle skooldissipline afhang van die hoof se toepassing van basiese (skool)administratiewe vaardighede op die volgende drie terreine, naamlik die organisatoriese struktuur van die skool self, die gedrag van opvoeders en die gedrag van leerders. Die oorsake van dissiplineprobleme kan buite hierdie drie dimensies lê, soos byvoorbeeld die ouerhuis, sosiale groep, gemeenskap en omgewingsfaktore, maar hierdie faktore lê buite die beheer van die skoolomgewing (Hartzell, 1992). Daar is ook breë eenstemmigheid oor wat 'n opvoeder nodig het ten einde effektief te wees: kennis van sy vak is deurslaggewend, asook die vermoë om 'n les te gee wat glad vloei en wat die leerlinge se aandag hou (Hartzell, 1992). Die derde terrein van bevoegdheid omvat 'n reeks vaardighede wat betrekking het op die beheer van groepe leerders, dit wil sê, groepbestuursvaardighede (vgl. Hartzell, 1992:70-72; Bear, 1998; Van den Aardweg \& Van den Aardweg, 1988):

- Die opvoeder behoort sy leerlinge as individue te ken. Dit beteken hy moet hulle name ken, hulle persoonlikhede, hulle belangstellings, asook wie hulle vriende is.

- Die opvoeder moet 'n klaskamer en 'n les op so 'n wyse kan beplan en organiseer dat leerders geïnteresseerd gehou en geleenthede vir ontwrigting geminimaliseer word. Dit beteken dat aandag geskenk moet word aan basiese aspekte soos die rangskikking van meubels, die groepering van leerders, die skakeling van werk met leerders se vermoë, die tempo van die les, die opvoeder se entoesiasme en die gebruik van humor om 'n positiewe klaskameratmosfeer te skep.

- Die klas moet voortdurend waargeneem word en die gedrag van die leerders gemonitor word.

- Die opvoeder moet voortdurend bewus wees van sy eie gedrag en sy eie gedrag beheer, insluitende sy liggaamshouding en stemtoon.

- Die opvoeder moet deur sy eie gedrag 'n rolmodel wees van die hoflikheid en standaarde wat hy van leerders verwag.

- Die opvoeder moet dit beklemtoon wat positief is, en moet goeie gedrag en goeie werk aanprys. 
- Die klaskamerreëls moet gedurende die eerste ontmoeting met die leerders duidelik gestel word, en daar moet ook aan leerders verduidelik word waarom dié reëls nodig is. Leerlinge behoort aktief betrokke te wees by die ontwikkeling van klaskamerreëls.

- Teregwysings moet met omsigtigheid gebruik word - konsekwent en so selde moontlik.

- Opvoeders moet leerlinge se opinies en bekommernisse respekteer.

- Straf moet eweneens omsigtig, konsekwent en so selde moontlik aangewend word.

- Die opvoeder moet sy eie bestuur en prestasie-uitkomste ontleed en daaruit leer.

- Die opvoeder moet voortdurend poog om die oorsaak van wangedrag by die leerlinge te bepaal.

- Die oorsaak van wangedrag lê dikwels opgesluit in die soeke na aandag. Selfs negatiewe aandag (van die opvoeder) is dan bevredigend (Thompson, 1994).

Wat skoolverwante faktore betref, is die volgende van belang. Op grond van die getuienis wat die Elton-kommissie versamel het, was dié Kommissie van oordeel dat skoolbestuur 'n deurslaggewende faktor is in die aanmoediging van 'n gevoel van gemeenskaplike verantwoordelikheid en toewyding onder leerders, ouers en opvoeders, wat weer bevorderlik is vir 'n neiging tot gedissiplineerde leerders wat hulle goed gedra (Department of Education and Science and the Welsh Office, 1989:13). Die Kommissie het bevind dat hoe groter die skool, hoe groter die kanse vir ontwrigting as gevolg van organisatoriese defekte (Department of Education and Science and the Welsh Office:1989:119). In die verslagdoening van die resultate van die empiriese ondersoek word ook gefokus op die invloed van skoolgrootte op die handhawing van dissipline in die Suid-Afrikaanse konteks. 'n Tweede saak wat hiermee verband hou, is die klasgrootte. Opvoeders het aangetoon dat kleiner klasse makliker beheer word (Johnson, 1993). Ouers se verwaarlosing van hulle opvoedingstaak kan ook ' $n$ rol speel. Die rol van die ouers word later in die artikel in meer besonderhede bespreek.

Ouers, as die primêre opvoeders van hulle kinders, is 'n belangrike faktor in die beïnvloeding van hulle kinders se dissipline op skool (Steyn et al., 2003:229). Twee belangrike faktore in ouerverwante determinante/korrelate van leerderdissipline is ouerbegeleiding en -voorbeeld, en ouer-skoolverhoudinge. Ouers speel 'n deurslag- 
gewende rol in die vorming van gesindhede wat goeie gedrag in die skoolsituasie tot gevolg het. Ouers behoort aan hulle kinders ferm leiding te gee en deur hul gedrag 'n positiewe voorbeeld te stel. Ouers behoort ook hulle kinders te begelei tot meewerkende verhoudingsluiting met volwassenes en ander kinders. Hulle moet alles in hulle vermoë doen om by hulle kinders dié waardes in te skerp waarop sowel die skool as die gemeenskap gebaseer is. Dié waardes sluit in selfrespek, asook respek vir en bedagsaamheid teenoor ander, selfdissipline en morele waardes soos eerlikheid en waarheidsgetrouheid. ${ }^{2}$ Die Elton-kommissie haal navorsing aan wat daarop dui dat leerders wat ernstige gedragsprobleme in skole openbaar, waarskynlik óf verwaarlosing (in die vorm van hetsy fisiese straf of permissiwiteit) óf verwerping by hulle ouerhuise beleef (Department of Education and Science and the Welsh Office, 1989:134).

Gesinspanning (dié term word hier aangewend om te verwys na die emosionele sowel as die fisiese spanning waaraan gesinne blootgestel mag word) soos egskeidings, huwelikspanning, armoede en swak behuising word deur navorsingsbevindings geïdentifiseer as aanleidende faktore tot die gedragsprobleme van leerders in skole (Department of Education and Science and the Welsh Office, 1989:135; Bear, 1998).

Verskeie studies dui op 'n positiewe verband tussen ouerbetrokkenheid by skole en gedissiplineerde gedrag van hulle kinders by dié skole (vgl. Department of Education and Science and the Welsh Office, 1989:124-127).

Samelewingsverwante faktore verwys na die voorbeelde van geweld, rassisme en ander antisosiale gedrag wat leerders deur die massamedia (veral televisie en videoprogramme) kry, en wat wangedrag en dissiplineprobleme kan veroorsaak (McHenry, 2000).

\subsection{Hantering van dissipline}

Tersaaklike vakliteratuur formuleer twee kategorieë aanbevelings oor hoe om dissipline te hanteer, naamlik skoolgebaseerde maatreëls en huisgebaseerde faktore.

2 Dit spreek vanself dat die Christenouer sal poog om aan hierdie waardes 'n Bybelsgefundeerde inhoud te gee. 
Wat die skool betref, behoort die betrokkenheid van alle rolspelers (hoof, ouers, opvoeders en leerders) gemaksimaliseer te word (Lovegrove et al., 1989:258) by die opstel en gereelde hersiening van skoolreëls en dissiplinêre beleid.

Terwyl die wetlike model (d.w.s. juridiese straf) die vergeldings-, afskrik-, en rehabiliterende funksies van straf erken, moet dissiplinêre maatreëls in 'n skool nie die opvoedingsdoelstellings ondermyn nie, en dus sover moontlik op die rehabiliterende aspek konsentreer (Lovegrove et al., 1989:260-261).

\section{Navorsingsontwerp}

\section{1 Steekproef en administratiewe prosedures}

Die 76 hoofde wat aan die ondersoek deelgeneem het, het hulle bereid verklaar om deel van die ondersoek te wees. 'n Beroep is deur middel van die Suid-Afrikaanse Opvoedersunie (SAOU) se kommunikasiekanale op hoofde van Afrikaanse skole gedoen om hulle aan te meld. Die steekproef wat gebruik is, is dus nie 'n verteenwoordigende steekproef nie, maar 'n beskikbaarheidsteekproef. Hoewel die besinning (vgl. 2 hierbo) oor dissipline, dissiplineprobleme en die rol van die verskillende opvoeders vanuit 'n reformatoriese denkraamwerk gedoen is, is besluit om hierdie prinsipiële perspektief nie in die vraelys in te bou nie, en wel om die volgende redes. Hoewel al die respondente Afrikaanssprekend was, was daar onsekerheid of hulle almal tot die Christelike geloof behoort. Die betrokke skole verteenwoordig 'n hele spektrum religieuse diversiteit onder sowel die onderwysers as die leerders. Bowendien was die doel met die ondersoek om slegs die omvang van die verskynsel "dissipline-probleme" in die betrokke skole te ondersoek. Die vraelys is gepos aan al die hoofde wat aangedui het dat hulle wil deelneem.

\subsection{Statistiese tegnieke 3}

Bepaling van frekwensies: Die frekwensies oor die biografiese gegewens en Afdeling $B$ van die vraelys is bepaal.

Bepaling van geldigheid van faktore in die vraelys: Sekere vrae in die vraelys is saamgroepeer ten einde vas te stel of hierdie

3 Die Statistiese Konsultasiediens van die PU vir $\mathrm{CHO}$ word bedank vir hulp met die verwerking van die statistiese gegewens. 
groeperings (faktore) as betroubaar gesien kan word in die konteks waarin dit gebruik is.

Bepaling van effekgrootte van verskille tussen skole van verskillende groottes: Vervolgens is skole gegroepeer in groter skole (skole met meer as 500 leerders) en kleiner skole (skole met minder as 500 leerders). Afdeling $\mathrm{C}$ se response is toe vergelyk - deur gebruik te maak van die d-waarde - ten einde te bepaal of daar beduidende verskille tussen groter en kleiner skole is.

\subsection{Bepaling van frekwensies: biografiese gegewens}

Uit die biografiese gegewens in die vraelys het die skole wat aan die ondersoek deelgeneem het die volgende beeld vertoon:

- Min skole het minder as 500 leerders. $75 \%$ van al die skole wat aan die ondersoek deelgeneem het, kan beskryf word as groot skole (meer as 500 leerders).

- Die meerderheid van die hoofde (51\%) wat deelgeneem het, kan beskryf word as senior hoofde, aangesien hulle op posvlak 4 was.

- Daar was 'n redelik goeie verspreiding van hoofde wat stedelike $(61 \%)$ en plattelandse $(39 \%)$ respondente betref.

- Die groot getal skole met meer as 20 personeellede $(63 \%)$ is in ooreenstemming met die respons soos gerapporteer by skoolgrootte, naamlik dat die meeste deelnemende skole as groot skole beskryf kan word.

- Van die skole in die ondersoek was $97 \%$ openbare skole.

- Daar was 'n goeie verspreiding van sekondêre (51\%), primêre (39\%) en gekombineerde (11\%) skole onder die respondente.

- Daar was goeie verteenwoordiging onder die respondente van al die tipes skole wat gekategoriseer is ten opsigte van multikulturaliteit. $22 \%$ van die skole het hulleself as heeltemal multikultureel beskryf, 9\% as hoofsaaklik monokultureel maar met meer as $30 \%$ van die leerders van ander kulture as die oorspronklike kultuurgroep, $33 \%$ as hoofsaaklik monokultureel maar met tussen $10 \%$ en $30 \%$ van leerders van ander kulture as die oorspronklike kultuurgroep, $33 \%$ as hoofsaaklik monokultureel met minder as $10 \%$ van leerders van ander kulture as die oorspronklike kultuurgroep en slegs $2 \%$ van skole was heeltemal monokultureel. 
- Van die responderende hoofde het $67 \%$ gemeen dat hulle personeel baie ervare is.

- Van die deelnemende hoofde het $78 \%$ gemeen dat hulle personeel positief ingestel is teenoor die onderwys as ' $n$ lewenslange roeping.

- Alle skole het 'n meerderheid leerders gehad wat die Christelike geloof aanhang. 4

- Van die hoofde het $41 \%$ gemeen dat die stand van leerderdissipline in hulle skole goed is, terwyl $51 \%$ gemeen het dat dit gemiddeld is en die res (9\%) gemeen het dat dit swak is of hulle het nie die vraag beantwoord nie.

\subsection{Bepaling van frekwensies: feitelike vrae oor die hantering van dissipline}

In afdeling $B$ van die vraelys is vrae gestel ten einde vas te stel hoe die skool met formele sake rondom leerderdissipline en dissiplinêre verhore handel.

B1. Hierdie skool het 'n geskrewe dissiplinêre gedragskode vir leerders

B2. Ouers is altyd teenwoordig by dissiplinêre verhore van hulle kinders

\begin{tabular}{|l|l|l|l|l|}
\hline \multicolumn{2}{|l|}{ Ja } & \multicolumn{2}{l|}{ Nee } & \multicolumn{1}{l|}{} \\
\hline $\boldsymbol{f}$ & $\%$ & $\boldsymbol{f}$ & $\%$ & $\begin{array}{l}\text { Onbe- } \\
\text { ant- } \\
\text { woord } \\
(f)\end{array}$ \\
\hline 75 & 100,0 & - & - & 1 \\
57 & 76,0 & 18 & 24,0 & 1 \\
\end{tabular}

$4 \quad$ Hierdie bevinding het - by nabaat - laat blyk dat daar wel in die vraelys 'n groter nadruk op ' $n$ Bybelsgefundeerde benadering tot dissipline en dissiplineprobleme kon gewees het. Dit bly egter 'n vraag of die vraelys deur die respondente verwelkom (en eerlik beantwoord) sou gewees het indien dit byvoorbeeld vrae oor die sondigheid van die mensdom en die sondegebrokenheid van die huidige menslike en skoolbedeling ingesluit het. 
B3. Hierdie skool het 'n "waarskuwingstelsel" (op skrif) wat as 'n voorloper tot dissiplinêre verhore dien

B4. Die verrig van take op die skoolterrein is deel van die straf wat aan leerders gegee word

B5. Strafklasse ná skool is deel van die straf wat aan leerders gegee word

B6. Daar is meer as 10 dissiplinêre verhore van leerders elke maand in hierdie skool

B7. Daar is minder as drie dissiplinêre verhore van leerders elke maand in hierdie skool

B8. Word lyfstraf nog in $u$ skool toegepas?

B9. Daar was by hierdie skool al 'n appèl teen skuldigbevinding deur ouers nadat hul kind skuldig bevind is aan 'n oortreding van die dissiplinêre kode

B10. Ek is soms die voorsitter van die dissiplinêre komitee tydens 'n verhoor

B11. Daar is al klagtes van aanranding deur ouers gelê teen 'n lid (of lede) van hierdie personeel

B12. Indien hierdie skool monokultureel was, sou ons minder dissiplineprobleme gehad het

\begin{tabular}{|c|c|c|c|c|}
\hline \multicolumn{2}{|l|}{ Ja } & \multicolumn{2}{|c|}{ Nee } & \multirow[b]{2}{*}{$\begin{array}{l}\text { Onbe- } \\
\text { ant- } \\
\text { woord } \\
\text { (f) }\end{array}$} \\
\hline$f$ & $\%$ & $f$ & $\%$ & \\
\hline 73 & 96,0 & 3 & 3,9 & - \\
\hline 42 & 55,2 & 34 & 44,7 & - \\
\hline 40 & 52,6 & 36 & $47, .3$ & - \\
\hline 5 & 6,6 & 70 & 93,3 & 1 \\
\hline 54 & 71,0 & 22 & 28,9 & - \\
\hline 7 & 9,2 & 69 & 90,7 & - \\
\hline 23 & 30,2 & 53 & 69,7 & - \\
\hline 17 & 22,6 & 58 & 77,3 & 1 \\
\hline 25 & 32,8 & 51 & 67,1 & - \\
\hline 21 & 27,6 & 55 & 72,3 & - \\
\hline
\end{tabular}


B13. Ek het dit al oorweeg om die onderwysprofessie te verlaat as gevolg van die verswakking van dissipline by leerders

B14. Daar is al ('n) leerder(s) deur die hoof van die provinsiale onderwysdepartement permanent uit hierdie skool geskors ná 'n aanbeveling van die skool

\begin{tabular}{|l|l|l|l|l|}
\hline \multicolumn{2}{|l|}{ Ja } & \multicolumn{2}{l|}{ Nee } & \multicolumn{1}{l|}{} \\
\hline $\boldsymbol{f}$ & $\%$ & $\boldsymbol{f}$ & $\%$ & $\begin{array}{l}\text { Onbe- } \\
\text { ant- } \\
\text { woord } \\
(f)\end{array}$ \\
\hline 20 & 26,3 & 56 & 73,6 & - \\
10 & 13,3 & 65 & 86,67 & 1 \\
\end{tabular}

- Dit is duidelik dat byna alle skole prosedures gereed gehad het vir die hantering van ongedissiplineerde leerders.

- Die wyses van straf verskil grootliks van skool tot skool. Die response by vrae B4 en B5 dui daarop dat daar nie eenvormige strawwe by skole is nie.

- Die respons by vraag B6 dui daarop dat daar 'n lae voorkoms van dissiplineprobleme is wat uitloop op dissiplinêre verhore. Daar kan aanvaar word dat dissiplineprobleme hanteer word voordat dit uitloop op 'n dissiplinêre verhoor.

- Die feit dat lyfstraf nog in $10 \%$ van die skole toegepas word (vraag B8) is onrusbarend, in die lig daarvan dat lyfstraf al sedert 1996 wetlik in skole verbied word.

- Dit is duidelik dat ouers hulle regte ken, aangesien twee-derdes van die ouers weet dat hulle mag appelleer teen 'n straf en dit inderdaad doen (vraag B9).

- Die feit dat sommige hoofde nog as voorsitter by dissiplinêre verhore optree (vraag B10) is strydig met die beginsel dat die hoof die aanklaer tydens dissiplinêre verhore moet wees.

- Slegs 'n kwart van die skole (vraag B12) meen dat daar minder dissiplineprobleme sou wees as die skool monokultureel was. 
4.5 Skoolhoofde se persepsie van die aard en omvang van dissiplinêre verhore in hulle skole

In Afdeling $C$ van die vraelys is ' $n$ aantal vrae gestel waar hoofde op 'n vierpuntskaal moes aantoon in watter mate hulle saamstem met 'n stelling wat gemaak is. Die indeling het gewissel van Baie selde tot Baie dikwels. Die vrae het veral gehandel oor aspekte soos die frekwensie waarteen dissiplinêre verhore plaasvind, die betrokkenheid van ouers by die verhore en die graad van die wangedrag wat by die skole voorkom.

\subsection{Bepaling van die betroubaarheid van die vrae in Afdeling $\mathrm{C}$}

- Vrae C1, C2 en C3 is saamgroepeer as 'n faktor, naamlik Die voorkoms van dissiplinêre verhore. Ten einde die betroubaarheid van hierdie faktor te bepaal in die konteks waarin dit gebruik is, is die Cronbach-alfa-betroubaarheidskoëffisiënt (Cronbach, 1949) bepaal. 'n Waarde van 0,85 is verkry, wat 'n aanduiding is dat hierdie groepering van vrae as betroubaar beskou kan word. Met die saamgroepering van vrae C8, C12 en C19 in 'n faktor, Ouerbetrokkenheid is 'n waarde van 0,36 verkry, wat dui op 'n laer mate van betroubaarheid. Die waarde wat verkry is met die saamvoeging van vrae C20, C21, C22 en C23 in 'n faktor, Ernstige wangedrag, is 0,48 , wat dui op 'n redelike mate van betroubaarheid.

\subsection{Die bepaling van die effekgrootte van die verskille tussen skole met skoolgrootte as onafhanklike veranderlike}

Die skole is verdeel in groter skole (meer as 500 leerders) en kleiner skole (minder as 500 leerders) ten einde prakties betekenisvolle verskille vir hierdie skole se response op die vrae in Afdeling $\mathrm{C}$ te bepaal. Indien daar 'n d-waarde van groter as 0,5 is, verteenwoordig dit ' $n$ verskil van mediumgrootte tussen twee groepe, terwyl 'n $d$ waarde van groter as 0,8 beteken dat daar 'n groot verskil tussen twee groepe is (Cohen, 1977). Verskille waar die d-waarde groter is as 0,5 (m.a.w. verskille van mediumgrootte) is by die respons op die volgende vrae gekry:

- Vraag C1, d-waarde =0,61. Daar vind dus beduidend meer dissiplinêre verhore by groter skole as by kleiner skole plaas. Vir die faktor Voorkoms van dissiplinêre verhore is 'n d-waarde van 0,63 verkry, wat die aanname in vraag $C 1$ bevestig. 
- Vraag C2, d-waarde =0,6. Meisies by groter skole is beduidend meer by dissiplinêre verhore betrokke as wat die geval by kleiner skole is.

\subsection{Bepaling van die effekgrootte van die verskille tussen skole met tipe skool as onafhanklike veranderlike}

Die skole is vervolgens verdeel in skole in stedelike en groter plattelandse gebiede (stedelik) aan die een kant en skole in kleiner plattelandse gebiede (plattelands) aan die ander kant ten einde prakties betekenisvolle verskille vir hierdie skole se response op die vrae in Afdeling $C$ te bepaal. Indien daar 'n d-waarde van groter as 0,5 is, verteenwoordig dit 'n verskil van mediumgrootte tussen twee groepe, terwyl 'n d-waarde van groter as 0,8 beteken dat daar ' $n$ groot verskil tussen twee groepe is (Cohen, 1977). Verskille waar die d-waarde groter is as 0,5 (m.a.w. verskille van mediumgrootte) is op die volgende vrae gekry:

- Vraag C1, d-waarde $=0,54$. Daar vind dus beduidend meer dissiplinêre verhore by stedelike skole as by plattelandse skole plaas. Vir die faktor Voorkoms van dissiplinêre verhore is ' $\mathrm{n} d$ waarde van 0,77 verkry, wat die aanname in vraag $\mathrm{C} 1$ bevestig.

- Vraag C20, d-waarde =0,55. Dwelmmisbruik as klag by dissiplinêre verhore kom beduidend meer by stedelike skole voor.

- Vraag C22, d-waarde $=0,63$. Ernstige aanranding as klag by dissiplinêre verhore kom beduidend meer by stedelike skole voor.

\subsection{Bepaling van die effekgrootte van die verskille tussen skole met kultuur as onafhanklike veranderlike}

Die skole is vervolgens verdeel in skole met 'n multikulturele aard (waar respondente afleiers 1 en 2 by vraag $A 7$ ingevul het) en skole met ' $n$ monokulturele aard (waar respondente afleiers 3, 4 en 5 by vraag A7 ingevul het), ten einde prakties betekenisvolle verskille vir hierdie skole se response op die vrae in Afdeling $C$ te bepaal. Indien daar 'n d-waarde van groter as 0,2 is, verteenwoordig dit 'n klein verskil tussen twee groepe, terwyl 'n d-waarde van groter as 0,5 beteken dat daar 'n mediumgrootte verskil tussen twee groepe is (Cohen, 1977). Slegs kleiner verskille (waar die d-waarde groter is as 0,2 ) is tussen die twee groepe skole gevind, en wel as respons op die volgende vrae:

- Vraag C3, d-waarde =0,23. Daar vind by skole met 'n multikulturele aard meer dissiplinêre verhore plaas waarby seuns betrokke is as by die meer monokulturele skole. 
- Vraag C19, d-waarde =0,34. Ouers by skole met 'n multikulturele aard is meer geneig om hul dankbaarheid uit te spreek oor die wyse waarop dissiplinêre verhore hanteer word as ouers by die meer monokulturele skole.

- Vraag C20, d-waarde =0,40. Dwelmmisbruik as rede vir dissiplinêre verhore kom meer by skole met 'n oorwegend multikulturele aard voor.

Bogenoemde kan daarop dui dat hoofde en personeel van multikulturele skole nog nie voldoende vaardighede het om die uitdagings van hierdie skole met betrekking tot dissipline te hanteer nie.

\section{Bespreking}

Die resultate van die ondersoek word vervolgens in verband gebring met die probleemvrae wat aan die begin van hierdie artikel gestel is.

Uit die tersaaklike vakliteratuur blyk dit dat dissiplineprobleme onder leerders ' $n$ universele verskynsel is. Die meerderheid probleme is matig van aard, maar dra daartoe by om die effektiewe uitvoering van opvoeders se take te verhinder. Die rol van die gesin in die voorkoms of afwesigheid van dissiplineprobleme by leerders is ook belangrik. In gesinne waar daar swak sosio-ekonomiese omstandighede of ander gesinsgebreke is, is daar 'n hoër voorkoms van dissiplineprobleme by die kinders.

In die ondersoek wat onder 76 skoolhoofde van skole met oorwegend Afrikaanssprekende leerders uitgevoer is, is 'n aantal sake uitgelig. Hierdie hoofde openbaar nie 'n gevoel van moedeloosheid oor die stand van dissipline in hulle skole nie. Hoofde bevind hulle duidelik in 'n nuwe omgewing waarin ouers en leerders hulle regte ken, maar die nodige prosedures word in werking gestel om hierdie nuwe omgewing te hanteer. Die (klein) groep skole waar ouers nie teenwoordig is by dissiplinêre verhore nie en die skole waar lyfstraf nog toegepas word, is nie verteenwoordigend van die meerderheid hoofde se denke en prosedures om dissiplineprobleme te hanteer nie.

'n Insiggewende bevinding is dat dissiplineprobleme nie in 'n baie groter mate voorkom in skole wat multikultureel geword het nie. Historiese persepsies dat Afrikaanssprekendes hulle wyse van hantering van dissipline (veral deur lyfstraf) as die enigste korrekte wyse van hantering sien, word nie deur hierdie navorsing ondersteun nie. Hoofde in Afrikaanse skole het die oorgang gemaak na 'n 
nuwe bedeling, met die gepaardgaande groter eis vir verantwoordelike en die prosedureel korrekte wyses om dissiplineprobleme te hanteer.

In groter, stedelike skole is die voorkoms van dissiplineprobleme hoër. Daar is egter nie 'n duidelike onderskeid te tref tussen groter, stedelike skole en kleiner, plattelandse skole nie. Albei tipes skole ervaar dieselfde soort dissiplineprobleme, met die voorkoms van ernstiger misdrywe net effens hoër in stedelike skole.

Daar kan aanvaar word dat Afrikaanse skole wat aan hierdie ondersoek deelgeneem het, tans daarin slaag om te voorkom dat dissiplineprobleme effektiewe onderwys bemoeilik. Daar is egter tendense te bespeur wat daarop dui dat beter samewerking tussen opvoeders, ouers en leerders noodsaaklik word ten einde die toename in die ernstigheid van dissiplineprobleme te voorkom.

Die prinsipiële besinning oor die vraagstuk van dissiplineprobleme in skole het egter 'n verdiepte perspektief na vore gebring (vgl. 2 hierbo). Die empiriese ondersoek het getoon dat hierdie betrokke groep skoolhoofde inderdaad met dissiplineprobleme in hulle skole worstel. Die ondersoek kon, weens die redes wat aangegee is, nie deurdring tot die werklike oorsaak of kern van die probleem nie, naamlik die teenwoordigheid van die sonde in hierdie wêreld nie. Dit is juis weens die sondegebrokenheid dat dissipline, in die sin van ware dissipelskap, nie meer tot sy reg kan kom nie. Dit is ook juis weens hierdie gebrokenheid van die huidige bedeling dat opvoeding (en dus ook opvoedende onderwys) 'n baie meer komplekse proses geword het. Opvoeding is in hierdie bedeling nie slegs die toerusting van die mens om met oorgawe God en die medemens te dien nie, maar het nou ook die dimensie bygekry om die "probleme" van die sonde (soos wangedrag by leerders) te bestry.

\section{Bibliografie}

ALTBACH, P.G. 1982. Servitude of the mind? Education dependering and neocolonialism. (In Altbach, P.G., Arnove, R.F. \& Kelly, G.R., eds. Comparative Education. New York : Macmillan. p. .)

ANON. 2002. Violence and discipline problems in US public schools: 19961997. [Web:] http://www.nces.ed.gov/pubs98/violence/98030001.html [Date of access: 23 April 2002].

BEAR, G.G. 1998. School discipline in the United States of America: prevention, correction and long term social development. School Psychology Review, 27(1):14-19. [In EBSCOHost: Academic Search Elite, Full display: http://www.sa.ebsco.com] [Date of access: 17 April 2002]. 
COHEN, J. 1977. Statistical power analysis for the behavioral sciences. New York : Academic.

CRONBACH, L.J. 1949. Essentials of psychological testing. 3rd ed. New York: Harper \& Row.

DEPARTMENT OF EDUCATION AND SCIENCE AND THE WELSH OFFICE (UNITED KINGDOM). 1989. Discipline in schools: Report of the Committee of Inquiry chaired by Lord Elton. London : HMSO.

DODD, A.W. 2000. Making schools safe for all students: - Why schools need to teach more than the 3 R's. NASSP Bulletin: 27-31, March.

FERNHOUT, H. 1997. Christian schooling: Telling a world-view story. (In Lambert, I. \& Mitchell, S. The crumbling walls of certainty. Macquarie Centre : The Centre for the study of Australian Christianity. p. 75-98.)

FIELDS, B.A. 2000. School discipline: Is there a crisis in our schools?. Australian Journal of Social Issues, 35(1):73-87. [In EBSCOHost: Academic. Search Elite, Full display: http://www.sa.ebsco.com]. [Date of access: 17 April 2002].

HARTZELL, G.N. 1992. The principle and discipline: working with school structures, teachers and students. The Clearing House, 65(6):376-381.

JOHNSON, B.O.M. 1993. Discipline in South Australian primary schools. Educational Studies, 19(4):289-306. [In EBSCOHost: Academic Search Elite, Full display: http:// www.sa. ebsco.com] [Date of access: 5 November 2002].

LOVEGROVE, M., LEWIS, R. \& BURMAN, E. 1989. Classroom discipline. (In Longford, P., ed. Educational Psychology. Melbourne : Longman. p. 255281.)

McHENRY, I. 2000. Conflict in schools. Fertile ground for moral growth. Phi Delta Kappan, 82(3):223-227.

MIDDLETON, J.R. \& WALSH, B.J. 1995. Truth is stranger than it used to be. Downer's Grove : InterVarsity.

MURRAY, O. 1995. Difficult to manage students: A survey of children - who fail to respond to student discipline. Educational Studies, 21(2):265-277.

NATIONAL CENTRE FOR EDUCATION STATISTICS (UNITED STATES OF AMERICA). 2002 Violence and discipline problems in U.S. Public Schools: 1996-97. [In EBSCOHost: Academic Search Elite, Full Display: http://www.sa.ebsa.com] [Date of access: 23 April 2002].

OOSTHUIZEN, I.J., ROUX, J.M. \& VAN DER WALT, J.L. 2003. A classical approach to the restoration of discipline in South African schools. Voorlopige manuskrip. Potchefstroom : Fakulteit Opvoedingswetenskappe.

PRETORIUS, J.W.M. 1979. Opvoeding, samelewing en jeug. Pretoria : Van Schaik.

STEYN, S.C., WOLHUTER, C.C., OOSTHUIZEN, I.J. \& VAN DER WALT, J.L. 2003. 'n Internasionale perspektief op leerderdissipline in skole. South African Journal of Education, 23(3):225-232.

THOMPSON, G. 1994. Discipline and the high school teacher. The Clearing House, 67(5):261-266.

VAN DEN AARDWEG, E.M. \& VAN DEN AARDWEG, E.D. 1988. Dictionary of empirical education/educational psychology. Pretoria : E\&E Enterprises.

VAN DYK, J. 1997. Letters to Lisa. Conversation with a Christian teacher. Sioux Centre : Dordt College Press.

VAN DYK, J. 2000. The craft of Christian teaching. Sioux Centre : Dordt College Press. 


\section{Kernbegrippe:}

Afrikaanse skole leerderdissipline

Key concepts:

Afrikaans schools learner discipline 